\title{
Ten years from propagule to mature plant of Butia purpurascens Glassman (Arecaceae): an endemic and endangered palm of the Brazilian Cerrado
}

\author{
Dez anos entre o propágulo e a planta madura de Butia purpurascens Glassman \\ (Arecaceae): uma palmeira endêmica e ameaçada de extinção do Cerrado brasileiro
}

\author{
K. Ressela* (D) and F. A. G. Guilherme ${ }^{b}$ (iD) \\ aUniversidade Federal de Jataí - UFJ, Programa de Pós-graduação em Geografia, Jataí, GO, Brasil \\ bUniversidade Federal de Jataí - UFJ, Unidade Acadêmica de Ciências Biológicas, Jataí, GO, Brasil
}

\begin{abstract}
With occurrence mainly in the southwest Goiás, Butia purpurascens has fruits and leaves widely extracted by the regional population. Coexists with exotic grasses, frequent burnings and cattle's grazing and trampling. Young individuals are rarely seen. We aim to provide information about propagules, seedling formation and the monitoring of saplings of B. purpurascens until adults in reproductive phase. Fruits were selected, measured and benefited after harvest. Of 6,000 fruits collected 3,112 were discarded for being perforated by Conotrachelus weevils. The experiment divided 2,600 fruits into 13 treatments, distributed in ripe and immature fruits, with and without pulp. In addition, we adopt mechanical and chemical break dormancy mechanisms, different storage periods and seeding depths. After sixteen months of monitoring, the formation of eleven seedlings was obtained without distinction of any treatment. Seedlings and saplings developed slowly, taking two years to emit the first metaphyll. Over time, ten individuals died, most from fungal attack. After ten years, the only surviving palm generated two inflorescences, which produced fruit. The inefficient seedling production and the slow development of saplings, combined with the impact of the extractivism and the high rate of predation of the pyrenes, suggest the low recruitment rate of the species observed, in natural conditions. This type of data is one of the important tools for creating guidelines for the species conservation. Therefore, we suggest considering the reclassification of B. purpurascens as a Critically Endangered species in the Official List of Threatened Brazilian Species of Extinction.
\end{abstract}

Keywords: conservation, critically endangered species, palm tree, propagation, seedlings.

\section{Resumo}

Com ocorrência concentrada no sudoeste goiano, Butia purpurascens tem frutos e folhas amplamente extraídos pela população regional. Coexiste com gramíneas exóticas, queimadas frequentes, além do pastejo e pisoteamento por gado. Os indivíduos jovens raramente são vistos. Este trabalho teve como objetivo fornecer informações sobre propágulos, formação de plântulas e monitoramento de indivíduos jovens de B. purpurascens até adultos em fase reprodutiva. Os frutos foram selecionados, medidos e beneficiados após a colheita. Dos 6.000 frutos coletados, 3.112 foram descartados por estarem perfurados por gorgulhos do gênero Conotrachelus. O experimento dividiu 2.600 frutos em 13 tratamentos, distribuídos em frutos maduros e imaturos, com polpa e despolpados. Além da adoção de mecanismos mecânicos e químicos de quebra de dormência, períodos de armazenamento e profundidades de plantio diferentes. Após 16 meses de monitoramento, a formação de 11 plântulas foi obtida sem distinção de qualquer tratamento. Plântulas e indivíduos jovens se desenvolveram lentamente, levando dois anos para emitir o primeiro metáfilo. Ao longo do tempo, dez indivíduos morreram, a maioria, por ataque fúngico. Após dez anos, a única planta sobrevivente gerou duas inflorescências, as quais produziram frutos. A capacidade de produção de plântulas ineficiente e o lento desenvolvimento das mudas, combinados com o impacto do extrativismo e a alta taxa de predação dos pirênios, sugerem a baixa taxa de recrutamento da espécie observada, em condições naturais. Esse tipo de dado é uma das ferramentas importantes para a criação de diretrizes para a conservação de espécies. Portanto, sugerimos considerar a reclassificação de B. purpurascens como espécie Criticamente Ameaçada na Lista Nacional Oficial de Espécies da Flora Brasileira Ameaçadas de Extinção.

Palavras-chave: conservação, espécie criticamente ameaçada, palmeira arborescente, propagação, plântulas.

*e-mail: kailarp@gmail.com

Received: February 11, 2020 - Accepted: July 10, 2020 


\section{Introduction}

Species extinction is a natural process in natural ecosystems, although anthropic actions hasten this process. Probabilistically, endemic and rare species are stronger candidates for extinction (Pimm, 1991; Scarano, 2006). This possibly occurs with Butia purpurascens Glassman, an endemic palm found in open areas of the Cerrado, distributing predominantly in the southwestern of Goiás state, but also in the Triângulo Mineiro and eastern portion of Mato Grosso do Sul (CNCFlora, 2012; Guilherme et al., 2015). Throughout of restricted distribution, there are no records of this palm within Conservation Units, such as Emas National Park (Parque Nacional das Emas) and other Natural Private Reserves. Additionally, several natural ecosystems in southwestern Goiás have already been decimated in the recent past, with few remnants still found under heavy pressure (Guilherme et al., 2020). Therefore, need to be preserved, to contribute to the maintenance of species. Thence, B. purpurascens was categorized as Vulnerable (VU) by The IUCN Red List of Threatened Species (Noblick, 1998), as Critically Endangered (CR) by the Biodiversitas Foundation (Fundação Biodiversitas, 2005) and as Endangered (EN) in the Official List of Brazilian Flora Species Threatened by Extinction (Lista Oficial das Espécies da Flora Brasileira Ameaçadas de Extinção) (Brasil, 2014). The vulnerability is certain, given the destruction of the Cerrado in last decades. Endangered and Critically Endangered species are those that are likely to be extinct in the near future.

Adult plants of $B$. purpurascens have a single stem, with heights varying between 1-7 $\mathrm{m}$ (Figure 1 ). The species is monoecious and light demanding; has strongly arched leaves, with petiole and rachis thornless. The spathe is lignified and glabrous from where the paniculate inflorescence arises. Flowers and fleshy and ovoid fruits (Figure 2A) have colors that range from yellow to purple (Lorenzi et al., 2010). The palm is widely used by the regional population in an extractive way, often associated with pasture areas (Figure 1 ), the species shows a decline in its populations, rarely, young individuals are observed in a natural environment (Guilherme et al., 2015).

As studies on the species propagation are nonexistent, we aims to provide information about propagules, seedling formation and the monitoring of new $B$. purpurascens individuals until adults in reproductive phase. This type of data is one of the important tools for creating guidelines for the species conservation and contributes as an indication of the characterization of the risk of extinction.

\section{Material and Methods}

Six thousand mature fruits of $B$. purpurascens were collected in November 2007, randomly from 120 matrices. The collect was made in natural areas of typical Cerrado and pastures of southwestern Goiás, in the counties of Jataí, Rio Verde, Aparecida do Rio Doce and Aporé. Of these, 3,112 were discarded because they were perforated by weevils (Coleoptera: Curculionidae).

Of the remaining fruits, 200 pulped and intact pyrenes (each unit of a drupoid fruit, consists of a woody endocarp and a seed) were stored in sealed glass jars in the shade to capture the weevils emerged. Fifty fruits and pyrenes were measured with a digital caliper and weighed in a digital analytical balance, and 2,600 were, immediately after processing, submitted into 13 pre-germination treatments (T): 1) Intact ripe fruits; 2) Intact immature fruits; 3) Partially pulped ripe fruit; 4) Pulped ripe fruit; 5) Pulped ripe fruits scarified with emery in one

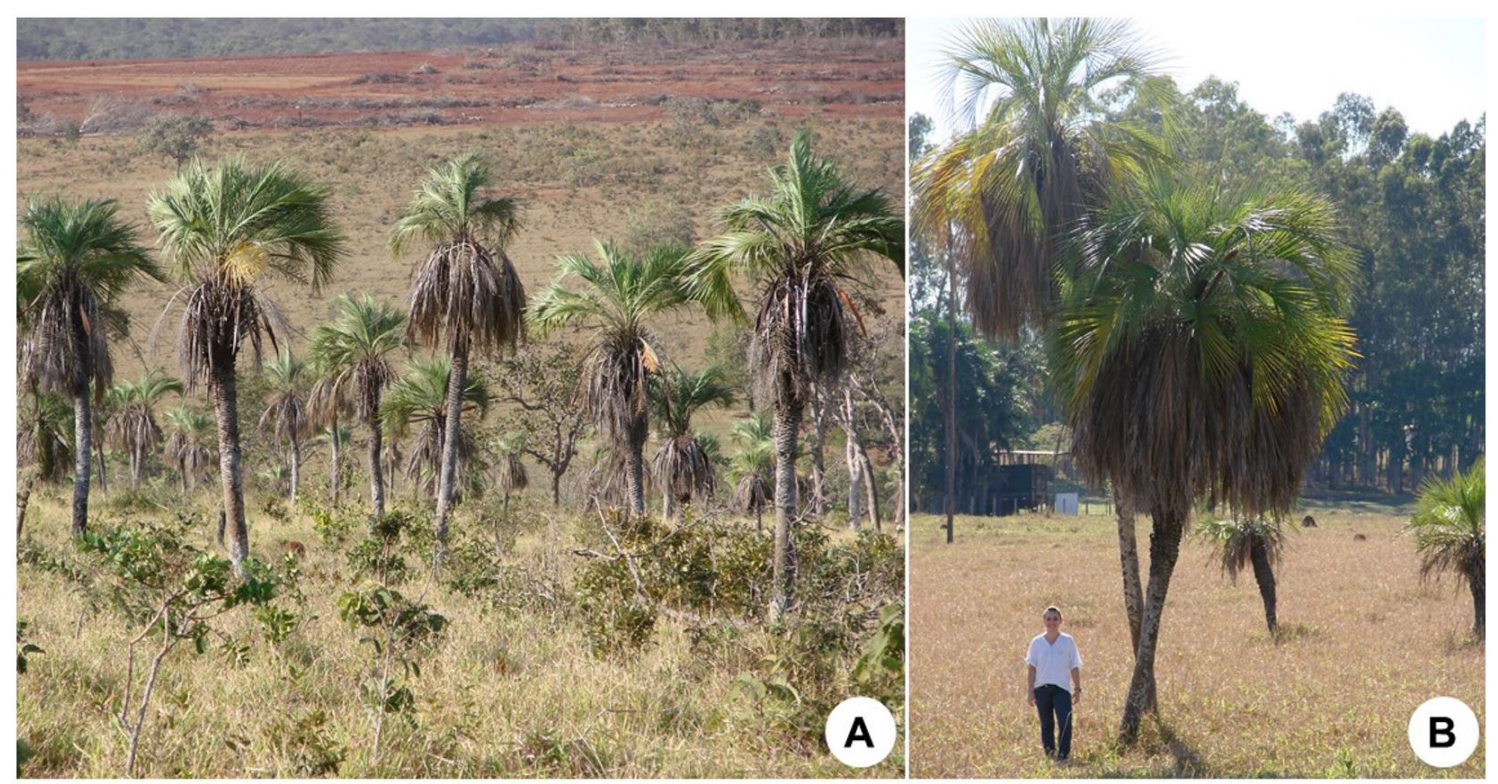

Figure 1. General view of Butia purpurascens population in southwest Goiás, with its leaves extracted (relived crown). In the foreground, some plants with inflorescence and immature infrutescences. In the background, the clearing of natural areas of Cerrado for agricultural use (A). Detail of individuals without extracted leaves. Note the large size (about 6-7 m heigth) of some individuals (B). Photos are from the authors. 

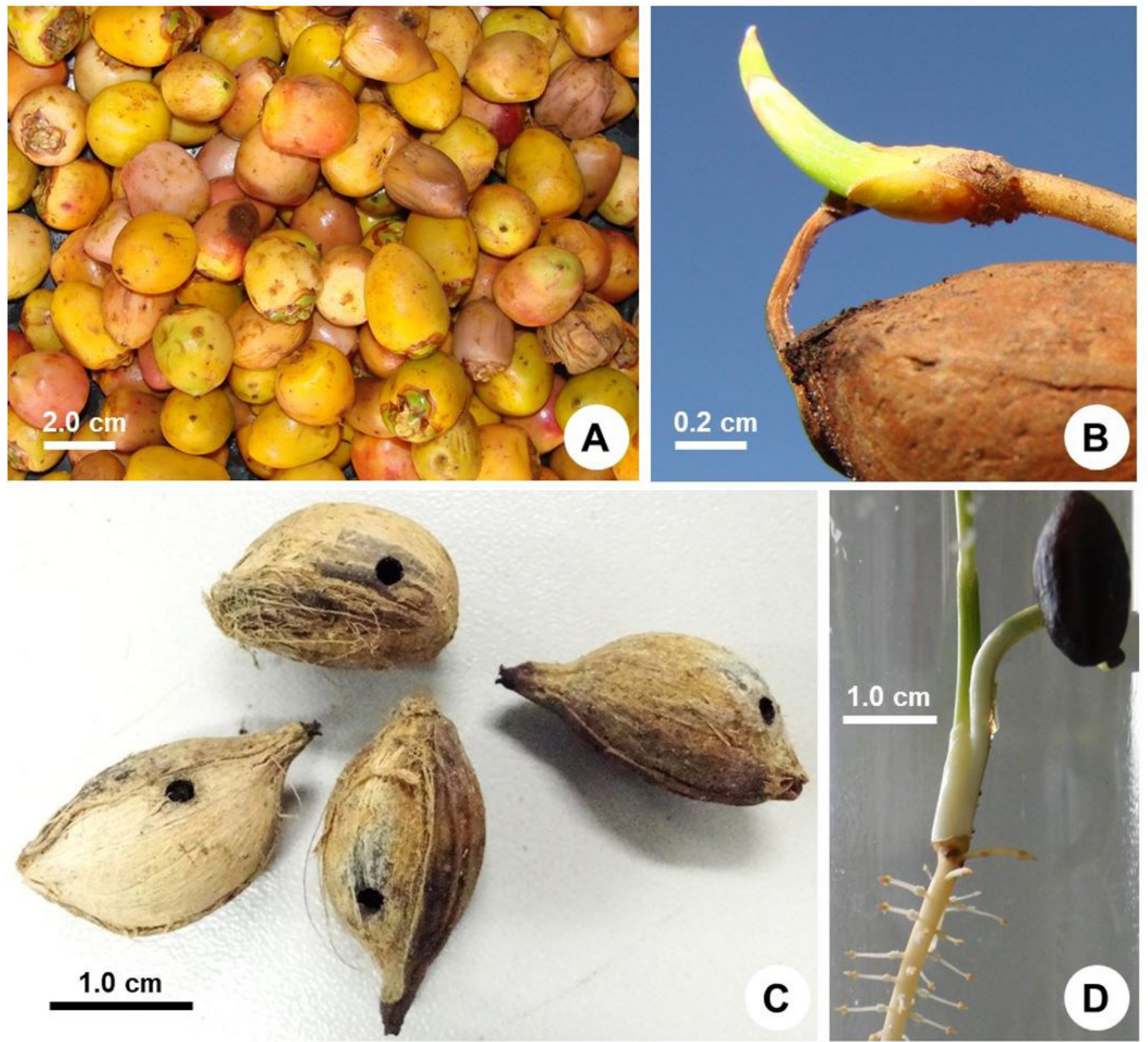

Figure 2. Details of fruits, pyrenes and seedling of Butia purpurascens. Mature fruits (A); stem primordium (B); predate pyrenes (C) and seedling showing root primordium (D). Credit to James Dean L. Rocha for Foto C. Other photos are from the authors.

of the germinative pores until orifice formation in the endocarp; 6) Ripe fruits pulped with caustic soda $20 \%$ for 20 minutes ( $\mathrm{NaOH}, \mathrm{Sol}{ }^{\circledR} 96-99 \%$ ) and then submerged in water for $12 \mathrm{~h}$; 7) Pulped ripe fruit scorched in the fire. For this, the pyrenes were deposited on the local natural litter, under a reproductive palm. To avoid accidents, the fire was started in a controlled way. The scorching time was around two minutes. The fire extinguished itself; 8) Pulped ripe fruits preserved in freezer for $1 \mathrm{~h} ; 9)$ Pulped ripe fruit sown on the surface of the substrate; 10) Pulped ripe fruit sown at $4 \mathrm{~cm}$ deep; 11) Pulped ripe fruits stored in paper bags at room temperature for 10 months and, in the driest month, August, sown after fire scorching; 12) Pulped ripe fruits, stored in paper bags at room temperature and sown after twelve months of storage; 13) Pulped ripe fruits stored in a refrigerator and sown after twelve months of storage. From T1 to T10 were sown immediately afterwards. The pulping meant the complete withdrawal of epicarp and mesocarp, leaving the pyrene.
The choice of treatments was based on methodologies available in the literature. Those that could simulate natural events in the Cerrado were used and adapted. Of the most common situations such as ripe or immature fruits, intact fruits, partially or totally pulped and buried by frugivores (T1, T2, T3 and T4). Fruits that are pulped by animals and left on the surface (T9) or buried at greater depths (T10). Fruits whose pyrenes can be cracked or broken by large fruit-eaters (T5) or swallowed and subject to chemical digestive action (T6). We tried to simulate the natural fires that affect areas of typical Cerrado physiognomy. In these areas the fire is fast, scorching the litter and grasses in the dry seasons (T7) and also that common situation in some species of the Cerrado, which disperse their propagules and, only after the action of the fire in the next dry season, breaks their dormancy (T11). Regional people report that in the past, frosts were strong and frequent in the region, leaving the fields white and cold in the morning. We tried to simulate the action of cold under the break of dormancy (T8). Those species that have propagules that 
maintain physiological quality for longer periods were also remembered (T12 and T13).

Each treatment consisted of 200 propagules, subdivided into 10 replicates. The blocks were randomly distributed in the experimental garden of the Federal University of Jataí (UFJ), in environmental conditions, under full sun and subject to climatic actions. The sowing of T1 to T10 was carried out in December 2007, the sowing of T11 was carried out in August 2008, and the T12 and T13 was carried out in December 2008. Under the same sowing conditions for all treatments: local soil, irrigation and light. The water used in the whole experiment was supplied by the underground collection of the UFJ artesian well. Seeding was carried out in plastic bags $(15 \times 10 \times 0.1-1 \mathrm{~kg})$ with local pure Latossolo soil, B Horizon. With the exception of surface or deep seeding treatments, all others had their propagules seeded under a thin layer of substrate. Automatic irrigations occurred daily.

From the formed seedlings, observations were made on the type of germination process (Henderson, 2006), type of seedling (Ressel et al., 2004), and morphology features of seedlings. As in some treatments the pyrenes were sown at $4 \mathrm{~cm}$ depth, the observation of seedling emergence was adopted as a reference for germination, not the root emission. To standardize, the term seedlings was used for all individuals with the first expanded eophyll. Normal plants were those without any structural deformations. The emergence was counted after the expansion of the stem primordium (Figure 2B). The emergence speed index (ES) was calculated by the method Maguire (1962). The number of normal seedlings emerged per day is widely used to predict the relative vigor of propagule samples, and can be obtained by the formula: $\mathrm{ES}=$ (number of normal seedlings/days until the first count $+\ldots .+$ number of normal seedlings/days until the final count).

After the end of the emergency evaluation, all the seedlings formed, of T1 to T10, were transferred to $10 \mathrm{~L}$ pots, aiming to monitor its development to observe the first flowering and fruiting. The conditions of soil, irrigation and light remained the same as in the germination experiment, only the volume of soil and container were increased. The vessels remained at the experiment site, once a year, in October, a new layer of soil (the same used in the experiment) was deposited on the surface of the pots, just enough to compensate for the loss of soil. As a complement, some measures were taken when individuals presented important information in their development. The growth of the young individuals was assessed by measuring the length of the stipe (from the collet to the apical meristem), the collet diameter and the leaves number. From there, pre-sowing treatments were not considered, since it does not show any influence on the emergence and seedling vigor. The 11 saplings were followed during the months when the parental plants were reproductive, September to January, in the expectation of observing the first flowering and fruiting. At the time of starting this reproduction, with viable flowers and forming fruits (within the normal morphological parameters for the species), the work was finished. The individuals were replanted, with substrate rich in organic matter and irrigation in the dry season. The experiment continued for T11, T12 and T13 in the same time, conditions and actions.

\section{Results}

The fruits (Figure 2A) showed, on average, $2.6 \pm 0.25 \mathrm{~cm}$ in length, $2.1 \pm 0.26 \mathrm{~cm}$ in width, and weight $7.10 \pm 1.83 \mathrm{~g}$ $(\mathrm{N}=50)$. The pyrenes, on average, had $1.9 \pm 0.2 \mathrm{~cm}$ in length, $1.0 \pm 0.08 \mathrm{~cm}$ in width, and weight $1.3 \pm 0.26 \mathrm{~g}$ $(\mathrm{N}=50)$. The predated pyrenes always presented the same pattern, a single hole, of constant size and shape (Figure 2C). The collected weevil was identified as the genus Conotrachelus, subfamily Molytinae. Although 3,112 pyrenes have been discarded by perforations for weevil and, only fully intact pyrenes have been used for treatments, yet, new perforations occurred along the experiment (Table 1). Although there are important differences in new perforations, between treatments, these were seen as totally random.

The first seedling of the experiment emerged after 314 days of sowing (October 2008), and the last one after 417 days (January 2009). None of the stored propagules generated seedlings. After 16 months of the experiment, 11 seedlings were formed, in total (Table 1) and all normal. There was no morphological difference between seedlings, between treatments nor in relation to the emergency number or seedling ES (Table 1). No abnormal seedling emerged.

Seedlings are crypto-hypogeal-reserve type (CHR). The germination is remote-ligular type (Figure 2D). The elongation of the cotyledonary petiole occurs through the opening of one circular operculum in the endocarp. When the cotyledonary petiole develops, it begins to dilate at its extremity from which the primary root emerges. Subsequently, a longitudinal slit is formed from which emerges the aerial part surrounded by the ligule. The caulinar primordium consists of two sheaths that develop, allowing the emergence of the eophyll.

In January 2009, month of the last emergency, information about 11 individuals were obtained, and developed slowly from seedlings to saplings, taking two years to emit the first pinnatisect leaf, the metaphyll. In January 2013, only three survivors remained, with $130.0 \pm 17.5 \mathrm{~mm}$ from the collet to the apical meristem, $43.0 \pm 6.3 \mathrm{~mm}$ of collet diameter, and $16 \pm 2.0$ leaves formed throughout their development. In December 2015 the only survivor produced the first inflorescence, without fruit formation. In December 2016 a new inflorescence was formed, without fruit formation. In December 2017, two inflorescences were produced, with fruit formation. After the first fruiting with morphologically normal fruits, the individual was transplanted, that despite the typical soil of the Cerrado, presents more organic matter and frequent manual irrigation. In December 2019, the mature individual flowering and fruiting, and stands $510 \mathrm{~mm}$ from the collet to the apical meristem and nine leaves. It is no longer possible to measure the diameter of collet due to remains of hard leaf petioles. The other ten individuals died with fungal attack symptoms, but no tests were performed for this. 
Table 1. Emergence of seedlings of Butia purpurascens Glassman, in 13 treatments, over 24 months of records of 2,600 propagules.

\begin{tabular}{|c|c|c|c|}
\hline Treatments & $\mathbf{E}$ & ES & $\mathbf{P}$ \\
\hline Intact ripe fruits & 1 & 0.02 & 15 \\
\hline Intact immature fruits with pericarp & 2 & 0.06 & 16 \\
\hline Partially pulped ripe fruit & - & - & 21 \\
\hline Pulped ripe fruit & 2 & 0.06 & 16 \\
\hline Pulped fruits scarified until orifice formation in the endocarp & 2 & 0.02 & 30 \\
\hline Fruits pulped with caustic soda for 20 minutes and then submerged in water for $12 \mathrm{~h}$ & - & - & 54 \\
\hline Pulped fruit scorched in the fire & 1 & 0.03 & 10 \\
\hline Pulped fruits preserved in freezer for $1 \mathrm{~h}$ & 2 & 0.03 & 47 \\
\hline Pulped fruit sown on the surface of the substrate & - & - & 16 \\
\hline Pulped fruit sown at $4 \mathrm{~cm}$ deep & 1 & 0.03 & 6 \\
\hline Pulped fruits stored at room temperature for 10 months and sown after fire scorching & - & - & - \\
\hline Pulped fruits, stored at room temperature and sown after twelve months & - & - & - \\
\hline Pulped fruits stored in a refrigerator and sown after twelve months & - & - & - \\
\hline
\end{tabular}

E: absolute number of seedlings formed; ES: emergency speed index; P: number of new pyrenes perforated during the experiment.

\section{Discussion}

Butia purpurascens showed low seedling formation capacity, as B. capitata (Martius) Beccari (Lopes et al., 2011) and B. catarinensis Noblick \& Lorenzi (Sampaio et al., 2012). This is common in Arecaceae, since low germination is associated with dormancy. In turn, this can be caused by immature embryos, mechanical resistance of pyrenes, impermeability to gases and/or water, presence of chemical inhibitors or these factors combined (Bewley and Black, 1994). So, an inefficient propagation was expected, but only eleven seedlings in 2600 propagules surprised, negatively. There are records of morphological dormancy in Arecaceae (Ferreira and Borghetti, 2004), and specifically for Butia (Becc.) Becc. (Reitz, 1974). The long period, around one year, for beginning the germinative process is common for the genus (Lopes et al., 2011; Sampaio et al., 2012). Some studies encourage the use of growth regulators or total withdrawal of the endocarp to increase the germinative potential (Broschat, 1998; Gentil and Ferreira, 2005; Ferreira and Gentil, 2006; Lopes et al., 2011). But that alone does not contribute to the species maintenance under natural conditions. Other studies like these can be essential for the domestication of the species and its re-introduction into nature. Or even, for commercial purposes, since it has landscaping potential and is widely used in the region for the manufacture of brooms. However, its slow growth can be challenging.

Guilherme and Oliveira (2011) demonstrated a clumped distribution pattern for individuals of the B. purpurascens. This resembles patterns of dispersers defecation, such as those of tapir (Tapirus terrestris Linnaeus, 1758). Santos (2017) considered Cerdocyon thous Linnaeus (1766) and T. terrestris as the main dispersers of Butia catarinenses Noblick \& Lorenzi playing a very important role in the species conservation, since they can travel great distances. A few decades ago, the occurrence of large and medium mammals in the Cerrado was much superior. The decline of populations of natural dispersers can also be added to the probable causes of the declining of B. purpurascens populations.

B. purpurascens shows fruit ripening only once a year, always starting in the rainy season (Guilherme et al., 2015). The seeds are strongly predated by larvae of weevils Conotrachelus. The genus, with about a thousand described species and many others to be classified, does not have others scientific records of interactions with the genus Butia. Many insects complete their life cycle inside palm seeds (Costa et al., 1988), where the larvae develop by feeding on the seed (Christianini, 2006). Ragusa-Netto (2019) reported high seed predation of Attalea geraensis Barb. Rodr by bruchid beetles in Cerrado. Curculionids of the Revena rubiginosa Boheman (1936) species have a species-specific relationship with Syagrus romanzoffiana (Cham.) Glassman and their larvae are considered one of the main predators of seeds of the species. $R$. rubiginosa females lay eggs at a time when the endocarp is still developing. The endosperm is partially or completely consumed by the larvae, which when they reach their fourth stage of development, dig an orifice through the endocarp to get out of the fruit and soak in the soil (Costa et al., 1988; AlvesCosta and Knogge, 2005; Christianini, 2006). The remoteligular germination type can also represent a disadvantage of the species. The elongation of the cotyledonary petiole can be a weak spot in the seedling. Conductor of reserves between pyrene and seedlings, if preyed or damaged early can represent the death of the seedling.

In Jataí region, studies showed smaller diameter classes in individuals of $B$. purpurascens in typical Cerrado and pasture (Bernasol and Lima-Ribeiro, 2010; Guilherme and Oliveira, 2011). This could evidence the presence of saplings in natural conditions. However, these observations demonstrate that saplings development takes a long time, taking four years for the circumference at the ground height reached $4.3 \mathrm{~cm}$ and the height of $13 \mathrm{~cm}$ from the collet to the apical meristem (there is still no stipe). 
Obviously, the sample size was insufficient for further statements. However, they were individuals protected from rouths of the natural environment, herbivory and competition. The point is that further studies are needed to estimate the occurrence of individuals in even smaller diametric classes in the field, so that we can have a real estimate of the species reproduction.

In addition, the aforementioned studies also report the presence of a large part of the individuals distributed in pastures or areas impacted by anthropic actions, current or past. Therefore, to a large extent, B. purpurascens populations are associated with exotic grasses. Considering the fragility of the seedlings, which is their survival rate in relation to competition, effects of fire and attack by pathogens when under drowning? Considering that after three years the seedling still doesn't have the stature to overcome the grasses? The lack of observations and records of seedlings of the species in the field indicate that further studies of the species maintenance in the Cerrado are needed.

In addition to the adversities faced by the species, there is predatory extraction. The use of fruits and leaves by the local population is an old custom. Brooms made with their leaves are very popular and sold in the trade. It is known that the extraction of leaves is related to the reduction in the production of new inflorescences and, in the reduction of the reproductive potential of individuals in palm populations under the effect of leaf extraction (Flores and Ashton, 2000; Anten et al., 2003; Endress et al., 2004), as well as verified by for B. purpurascens (Guilherme et al., 2015).

\section{Conclusion}

Our results demonstrated high pyrene predation, low seedling production, slow growth of young individuals and a long time before the species reaches reproductive maturity. Furthermore, the southwestern of the Goiás state is one of the largest grain producers in Brazil, with a history of strong degradation of remnants where the species naturally occurs. Protected areas could increase the effectiveness of conservation and improve scientific knowledge not only from the the Brazilian Cerrado, but particularly from B. purpurascens. Associated with the constant leaves and fruits extraction, the severe threat of this palm species is imminent. More studies on reproductive aspects, plant survival and establishment in the field are needed, in addition to a better understanding of the high propagules predation and diseases that attack seedlings in the field. Thus, we suggest to consider the reclassification of $B$. purpurascens as a Critically Endangered species in the Official List of Threatened Brazilian Species of Extinction and by The IUCN Red List of Threatened Species.

\section{Acknowledgements}

To the researchers Bruno Medeiros and Sérgio A. Vanin for the weevil identification. To the researcher Flor Henderson for the assistance with the seedling germination type. To PNPD/CAPES for financing post doc scholarship (nº 88882.306497/2018-01). To FAPEG and CNPq for financial support (PELD-Jataí/Process nํ 2017/1026 7000 329).

\section{References}

ALVES-COSTA, C.P. and KNOGGE, C., 2005. Larval competition in weevils Revena rubiginosa (Coleoptera: Curculionidae) preying on seeds of the palm Syagrus romanzoffiana (Arecaceae). Naturwissenschaften, vol. 92, no. 6, pp. 265-268. http://dx.doi. org/10.1007/s00114-005-0620-6. PMid:15871001.

ANTEN, N.P.R., MARTÍNEZ RAMOS, M. and ACKERLY, D.D., 2003. Defoliation and growth in an understory palm: quantifying the contributions of compensatory responses. Ecology, vol. 84, no. 11, pp. 2905-2918. http://dx.doi.org/10.1890/02-0454.

BERNASOL, W.P. and LIMA-RIBEIRO, M.S., 2010. Estrutura espacial e diamétrica de espécies arbóreas e seus condicionantes em um fragmento de Cerrado sentido restrito no sudoeste goiano. Hoehnea, vol. 37, no. 2, pp. 181-198. http://dx.doi.org/10.1590/ S2236-89062010000200001.

BEWLEY, J.D. and BLACK, M., 1994. Seeds: physiology of development and germination. New York: Plenum Press. . http://dx.doi. org/10.1007/978-1-4899-1002-8.

BRASIL. Ministério do Meio Ambiente - MMA, 2014 [viewed 11 February 2020]. Lista Nacional Oficial de Espécies da Flora Ameaçadas de Extinção [online]. Available from: https://ckan.jbrj.gov.br/dataset / 23f2e24c-5676-4acd83f0-03621cba4364 / resource / 8d0bbe11-e7d4-49c398ba-c07f2dfacf5e / download / portariamma4432014 / listaespeciesfloraameacadasextincaobrasil

BROSCHAT, T.K., 1998. Endocarp removal enhances Butia capitata (Mart.) Becc. (Pindo Palm) seed germination. HortTechnology, vol. 8, no. 4, pp. 586-587. http://dx.doi.org/10.21273/ HORTTECH.8.4.586.

CENTRO NACIONAL DE CONSERVAÇÃO DA FLORA - CNCFLORA, 2012 [viewed 11 February 2020]. Butia purpurascens. In: CENTRO NACIONAL DE CONSERVAÇÃO DA FLORA - CNCFLORA, ed. Lista vermelha da flora brasileira [online]. Rio de Janeiro: CNCFLORA. Available from: http://cncflora.jbrj.gov.br/portal/pt-br/profile/ Butia purpurascens

CHRISTIANINI, A.C., 2006. Fecundidade, dispersão e predação de sementes de Archontophoenix cunninghamiana H. Wendl. \& Drude, uma palmeira invasora da Mata Atlântica. Revista Brasileira de Botanica. Brazilian Journal of Botany, vol. 29, no. 4, pp. 587-594. http://dx.doi.org/10.1590/S0100-84042006000400008.

COSTA, C., CASARI, S.A. and VANIN, S.A., 1988. Larvas de coleóptera do Brasil. São Paulo: Museu de Zoologia, Universidade de São Paulo. http://dx.doi.org/10.5962/bhl.title.100233.

ENDRESS, B.A., GORCHOV, D.L. and NOBLE, R.B., 2004. Non-timber forest product extraction: effects of harvest and browsing on an understory palm. Ecological Applications, vol. 14, no. 4, pp. 1138-1153. http://dx.doi.org/10.1890/02-5365.

FERREIRA, A.G. and BORGHETTI, F., 2004. Germinação: do básico ao aplicado. Porto Alegre: Artmed.

FERREIRA, S.A.N. and GENTIL, D.F.O., 2006. Extraction, imbibition and germination of Astrocaryum aculeatum seeds. Acta Amazonica, vol. 36, no. 2, pp. 141-145. http://dx.doi.org/10.1590/S004459672006000200002.

FLORES, C.F. and ASHTON, P.S., 2000. Harvesting impact and economic value of Geonoma deversa, Arecaceae, an understory palm used for roof thatching in the Peruvian Amazon. Economic Botany, vol. 54, no. 3, pp. 267-277. http://dx.doi.org/10.1007/BF02864781. 
FUNDAÇÃO BIODIVERSITAS, 2005 [viewed 11 February 2020]. Lista da flora brasileira ameaçada de extinção [online]. Available from: http://www.biodiversitas.org.br/florabr/lista_florabr.pdf

GENTIL, D.F. and FERREIRA, S.A.N., 2005. Morfologia da plântula em desenvolvimento de Astrocaryum aculeatum Meyer (Arecaceae). Acta Amazonica, vol. 35, no. 3, pp. 339-344. http://dx.doi. org/10.1590/S0044-59672005000300005.

GUILHERME, F.A.G. and OLIVEIRA, A.S., 2011. Estrutura populacional de Butia purpurascens Glassman (Arecaceae) em duas áreas de Cerrado sensu stricto no estado de Goiás. Revista de Biologia Neotropical, vol. 7, no. 1, pp. 37-41. http://dx.doi.org/10.5216/ rbn.v7i1.13853.

GUILHERME, F.A.G., MARICATO, H.S., MARIMON, B.S., PEREIRA, F.C., SOUZA, L.F., COELHO, C.P., FERREIRA, W.C., FERREIRA JÚNIOR, A. and PEREIRA, K.A.R., 2020. Man-made soil drainage alters the vegetation structure and woody species distribution in campo de murundus. Acta Scientiarum. Biological Sciences, vol. 42, pp. e49894. http://dx.doi.org/10.4025/actascibiolsci.v42i1.49894.

GUILHERME, F.A.G., VASCONCELOS, E.I., COELHO, C.P., RESSEL, K., BATISTA, N.T.F. and SOUZA, L.F., 2015. Vegetative and reproductive phenology of Butia purpurascens Glassman (Arecaceae) under the effects of leaf harvesting. Brazilian Journal of Biology $=$ Revista Brasileira de Biologia, vol. 75, no. 1, pp. 77-85. http://dx.doi. org/10.1590/1519-6984.07513. PMid:25945623.

HENDERSON, F., 2006. Morphology and anatomy of palm seedlings. Botanical Review, vol. 72, no. 4, pp. 273-329. http://dx.doi. org/10.1663/0006-8101(2006)72[273:MAAOPS]2.0.CO;2.

LOPES, P.S.N., AQUINO, C.F., MAGALHÃES, H.M. and BRANDÃO JÚNIOR, D.S., 2011. Tratamentos físicos e químicos para superação de dormência em sementes de Butia capitata (Martius) Beccari. Pesquisa Agropecuária Tropical, vol. 41, no. 1, pp. 120-125. http:// dx.doi.org/10.5216/pat.v41i1.8388.

LORENZI, H., NOBLICK, L.R., KAHN, F. and FERREIRA, E., 2010. Flora Brasileira: Arecaceae (palmeiras). Nova Odessa: Ed. Plantarum.

MAGUIRE, J.D., 1962. Speed of germination - AID in selection and evaluation for seedling emergence and vigor. Crop Science, vol. 2, no. 2, pp. 176-177. http://dx.doi.org/10.2135/cropsci1962.00 11183X000200020033x.
NOBLICK, L., 1998. Butia purpurascens. In: INTERNATIONAL UNION FOR CONSERVATION OF NATURE - IUCN, ed. The IUCN Red List of Threatened Species 1998. e.T38463A10120736. Gland: IUCN. https://dx.doi.org/10.2305/IUCN.UK.1998.RLTS. T38463A10120736.en

PIMM, S.L. 1991. The balance of nature? Ecological issues in the conservation of species and communities. Chicago: University of Chicago Press.

RAGUSA-NETTO, J., 2019. Density-dependent seed predation in Attalea geraensis Barb. Rodr. (Arecaceae) caused by bruchid beetles in the Brazilian Cerrado. Brazilian Journal of Biology = Revista Brasileira de Biologia, vol. 79, no. 4, pp. 577-583. http:// dx.doi.org/10.1590/1519-6984.183318. PMid:30365636.

REITZ, R. 1974. Palmeiras. In: P.R. REITZ, ed. Flora ilustrada catarinense. Itajaí: Herbário Barbosa Rodrigues, 189 p.

RESSEL, K., GUILHERME, F.A.G., SCHIAVINI, I. and OLIVEIRA, P.E., 2004. Ecologia morfofuncional de plântulas de espécies arbóreas da Estação Ecológica do Panga, Uberlândia, Minas Gerais. Revista Brasileira de Botanica. Brazilian Journal of Botany, vol. 27, no. 2, pp. 311-323. http://dx.doi.org/10.1590/S010084042004000200010.

SAMPAIO, L.K.A., PERONI, N. and HANAZAKI, N., 2012 [viewed 11 February 2020]. Influência da despolpa do fruto e do choque térmico na germinação de Butia catarinensis Noblick \& Lorenzi. Revista Brasileira de Biociências [online], vol. 10, no. 1, pp. 127130. Available from: http://www.ufrgs.br/seerbio/ojs/index. php/rbb/article/view/1990

SANTOS, N.N., 2017 [viewed 11 February 2020]. Estudo da dispersão do Butia catarinensis Noblick \& Lorenzi no Parque Estadual da Serra do Tabuleiro, Palhoça, SC [online]. Florianópolis: Departamento de Ecologia e Zoologia, Universidade Federal de Santa Catarina, 37 p. Trabalho de Conclusão de Curso em Ciências Biológicas. Available from: https://repositorio. ufsc.br/bitstream/handle/123456789/176844/TCC\%20-\%20 Santos\%2C\%20Natália.pdf?sequence=1\&isAllowed=y

SCARANO, F.R., 2006. Prioridades para conservação: a linha tênue que separa teorias e dogmas. In: C.F.D. ROCHA, H.G. BERGALLO, M. VAN-SLUYS and M.A.S. ALVES, eds. Biologia da conservação: essências. São Carlos: RiMa, pp. 23-39. 